\title{
EFFECTIVENESS OF SOFT WALL CAPPING IN CONSERVING RUINS
}

\author{
Richard Schlesinger \\ Asst. Prof., PhD., Academy of Fine Arts and Design in Bratislava, SLOVAKIA, \\ schlesinger@vsvu.sk
}

\begin{abstract}
This article deals with the effect of soft wall caps as protection against the action on authentic historical structures by erosive effects of climate change. The main objective of this work is to prove, that the soft wall cap is the optimal choice of protection for the conservation of ruins wall-head masonry compared to different protection options. The work assesses the current state of preservation of building ruins in Slovakia, explains the methodological principles for the conservation and restoration of building access ruins, and discusses material and structural nature torsos and operation degradation effects on these structures. Selected areas with vegetation cover are examined by analyzing photos of the area, upon which the appropriate mix of veg. cover is evaluated. We also realize in-situ temperature-humidity experiment that brings efficiency and properties of soft capping on sites of Kláštorisko and Čachtice castle.
\end{abstract}

Keywords: Conservation, Soft-wall capping, Ruins, Degradation

\section{INTRODUCTION}

The circumstances that led to the choice of this topic was mainly the idea of using environmental-friendly, relatively inexpensive and economically acceptable system of protection of cultural monuments. In the protection of monuments, the work deals exclusively to torsional historic architecture, in other words ruins. The ruins are a natural part of the cultural landscape. Slovakia is a superpower in the number of castles, there are 300 castles of which 74 are in a state of ruins (Plaček, Bóna, 2007, p. 390). Currently, we can finish building ruins (reconstruct) if we have sufficient knowledge and technical possibilities of recovery. But only in some cases the choice is right. Conservation is more appropriately preservation whose task is to maintain the monuments, which can in some way to breathe new life into the monument (Kolektív Autorov. 2006, p. 144).

The main objective of this article is to prove that the soft wall capping is the optimal choice of protection for the preservation of masonry crown compared to other protection options. The object of the experiment will work on selected locations.

Wall cap is the top of a masonry structure, which was usually originally completed by some of the structural modifications that limited the natural erosive effects (roofing, stone slabs, sloping, etc.). These modifications have mostly disappeared and so there is a gradual loosening of the wall cap and the disappearance of the upper layer of the structure (Kohút, Staník, Závacký, Makýš, 2010, p. 68). These erosive effects have negative effect to characteristic compressive, flextural and shear strength of masonry walls. (Shawkat, 2017, p.152). 
The realization of soft wall caps in Slovakia is negligible for the number of our ruins. This technology is rather in the experimental phase in our country. The topic is addressed by a few specialists - technologists, archaeologists, structural engineers and methodologists. Finding locations was quite difficult. For advices I'm thankful, especially to my consultant assoc prof. Otto Makýš, PhD., methodologist Ing. arch. Martin Bóna and structural designer assoc. prof. Sabah Shawkat, Phd.

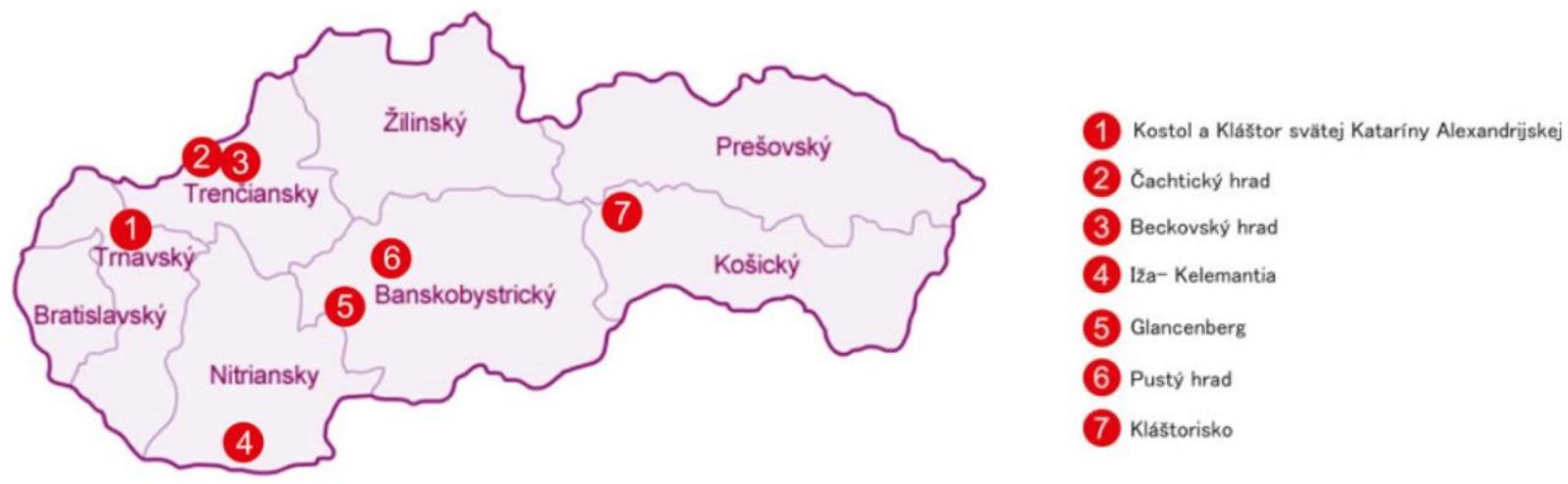

Fig. 1. Locations of soft wall capping in Slovakia (Schlesinger, 2015)

Several facts emerged from the photo-analyses. From the analyzed wall caps, we can divide their cap in three different ways. The first option is the end of the cap, the so-called "flower pot". The second one we encountered is the cap with a longitudinal full-area vegetation cover and the last third possibility is the termination of the crown into a concave shape. We can state that the first two options did not work in the analyzes we selected. Type "flower pot" cap is not suitable due to degradation of stones in the edges of masonry (Kreuziger, 2010, p.13). Second method is also problematic in edges of masonry, soft capping has tendencies to fall out from the edges. The third method seems to be the optimal solution for the method of placing the soft wall cap.
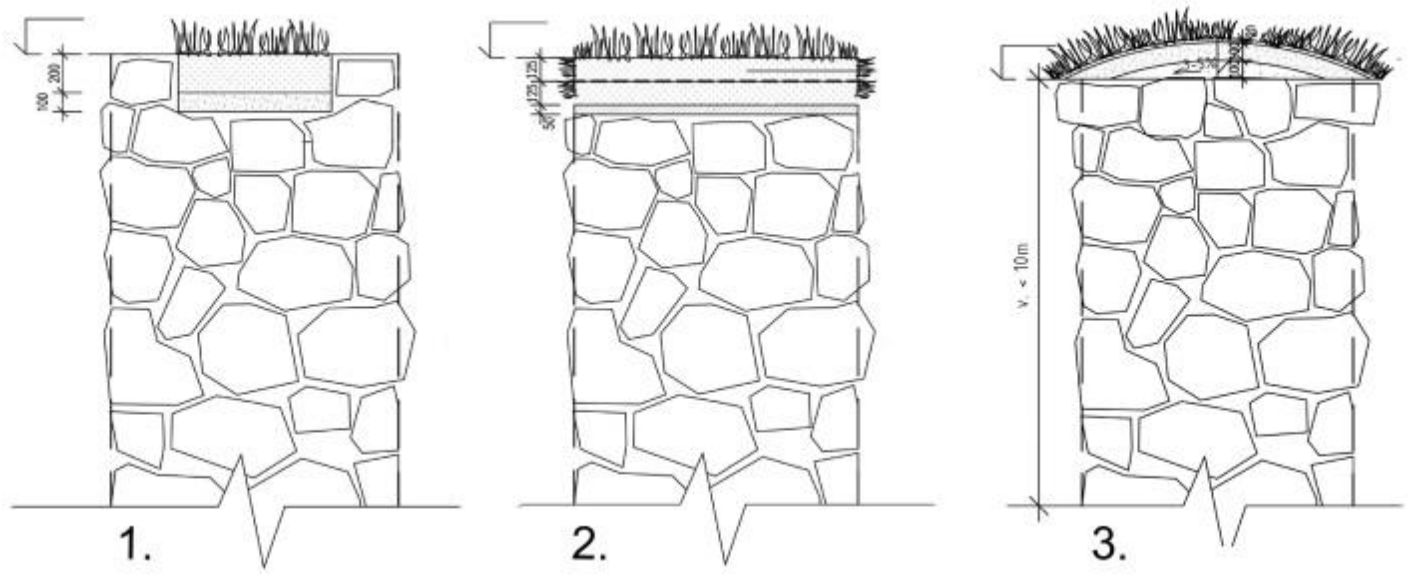

Fig. 2. Types of soft wall capping, 1- type "flower pot", 2- longitudinal full-soft capping, 3- concave soft capping (Schlesinger, 2015)

From the analysis, we have also learned that the choice of thickness is also an important factor. The thickness of $50 \mathrm{~mm}$ would be problematic. We therefore recommend a minimum thickness of $50 \mathrm{~mm}$ soft capping. 

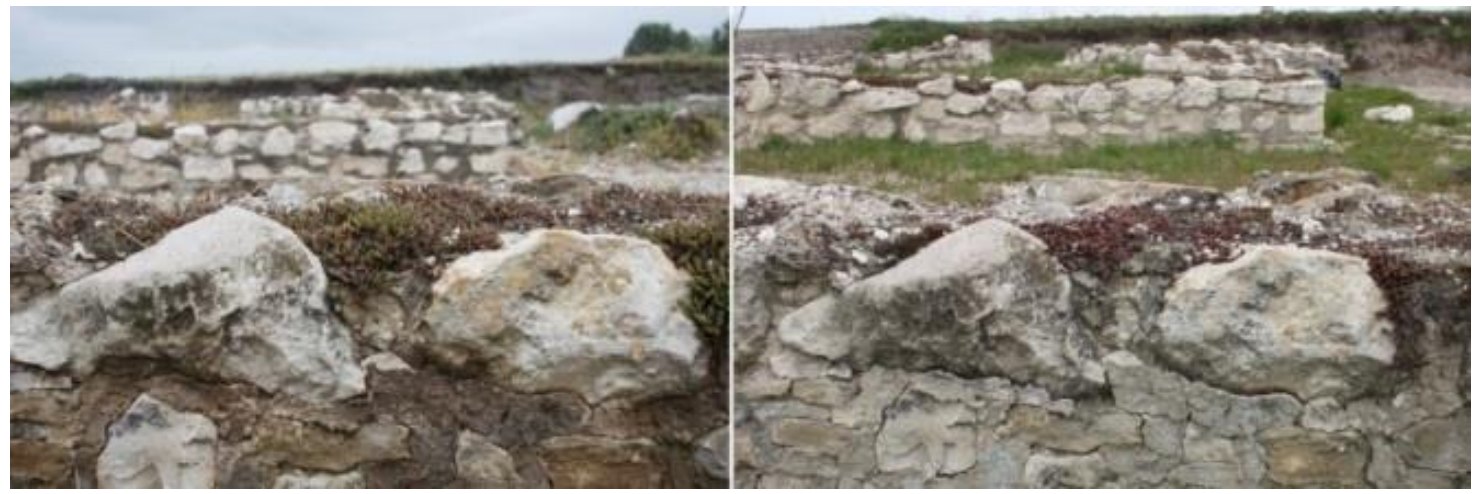

Fig. 3. Example of photo analysis in lža- Kelemantia. Left side 2011, Right side 2015 (Schlesinger, 2015)

There is also recommended for extremely dry and sunny sites with poor soil some ground cover plants. Snowflake-Iberis sempervirens, Angelina-Sedum reflexum, Geranium dalmaticum, Arenaria Montana Festuca ovina, Royal red - Aubrieta hybrid (Kohút, 2010).

\section{EXPERIMENT}

\subsubsection{Experiment Kláštorisko}

The experiment consisted of matched temperature and relative humidity, vegetation cover and masonry wall cap. Data were obtained in January 2014. The length of measurement was 5 days. Strain was monitored and recorded on datalogger_pc micro recobox th. The values are being recorded every hour. The temperature and relative humidity in various thickness of the vegetation cover was tested in this experiment

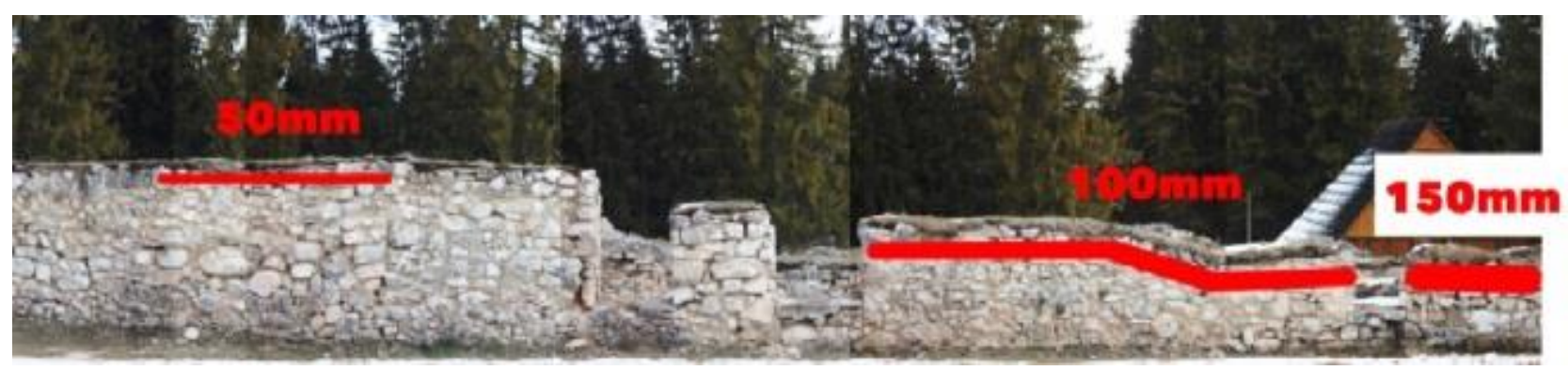

Fig. 4. Soft wall capping with difficult thickness in Kláštorisko site (Schlesinger, 2015)

\subsubsection{Experiment Čachtice castle}

The experiment consisted in comparing the temperature and humidity profiles of the soft wall cap and the hard wall cap. Data were obtained in April 2015 and June 2015. The duration of the measurement was 1 week. The course of temperatures was monitored and recorded on a datalogger_pc micro recobox th.

The investigated wall is oriented to the west side. It is covered along a length of $23 \mathrm{~m}$ with a continuous layer of vegetation cover with an average thickness of $100 \mathrm{~mm}$ without a specific flora composition. The blanket was removed in-situ. Parts of turf were cut and applied to the masonry crown $2 \mathrm{~m}$ long. The implementation took place in June 2014.

After the inspection, it was seen that the roots are not fused to the ground. This made it easy to insert the datalogger under the cover. Datalogger no. 1 was not packed in a plastic bag as in the experiment in the Monastery. Datalogger no. 2 was inserted into the joint in the masonry at the crown and was oriented to the outside of the wall. It was secured against slipping. The position of the temperature and humidity recorders can be seen in fig. 5 . 


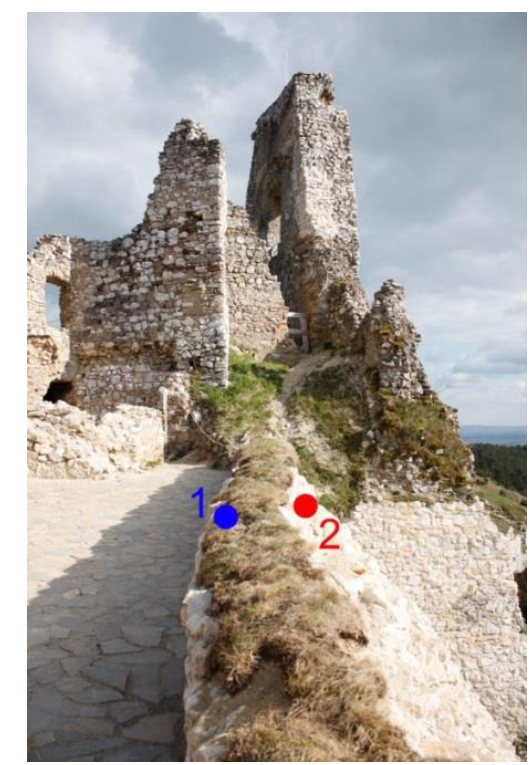

Fig.5. Positioning of dattaloggers in Čachtice castle (Schlesinger, 2015)

Temperature and relative humidity measurement we also realized in June 2015. It was a matter of verifying the effectiveness of the soft wall cap in extreme temperature conditions. We performed the measurement at a time when, in principle, there were no significant temperature changes. Temperatures ranged constantly from $15^{\circ} \mathrm{C}$ at night to $30^{\circ} \mathrm{C}$ during the day.

\section{RESULTS}

The experiment in Kláštorisko confirmed to us that the thickness over $50 \mathrm{~mm}$ to $150 \mathrm{~mm}$ does not have a significant effect on the efficiency of the cap, resp. that the temperature difference compared to the thickness is minimal. This means that for efficient and economical use we recommend to move in the values of the cover thickness between $50 \mathrm{~mm}$ and $100 \mathrm{~mm}$.

In the second experiment, we found that the $50 \mathrm{~mm}$ thick cover is able to accumulate temperature and most importantly at temperatures below $0^{\circ} \mathrm{C}$ is able to maintain the temperature above $0^{\circ} \mathrm{C}$, compared to the masonry crown, where there was again during the day and night. the freezing and thawing process, which results in the degradation of the masonry.

Another finding was that the cover can accumulate a sufficient amount of heat on cold days, see 4.1.2014 was at 16.00 . temperature difference up to $5^{\circ} \mathrm{C}$ compared to a brick crown.

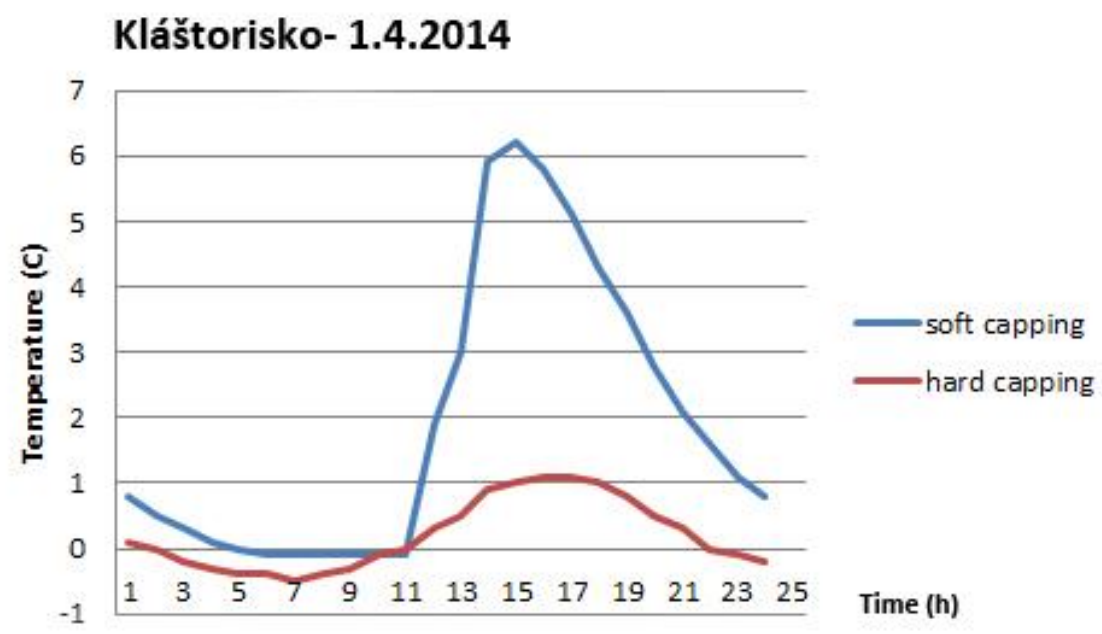

Fig. 6. Daily measurement in Kláštorisko site (Schlesinger, 2015) 
The results of measurements during the spring period in Čachtice showed that the vegetation cover is able to reduce rapid temperature changes that affect the crown of the masonry. The largest measured temperature difference was 15.4.2015, the difference between temperatures was at $19.00 .5 .4^{\circ} \mathrm{C}$. From the measured results in the given locality, we can confirm that the surface under the cover is less exposed to extreme temperature changes. In this case, the vegetation cover is able to dampen the consequences of temperature fluctuations. High temperatures and especially temperature fluctuations cause greater stress and expansion of materials also in our case of lime mortar, which can have consequences for the gradual degradation of masonry.

By measuring the relative humidity in the spring, we found that the vegetation cover is able to maintain a certain level of relative humidity, which ranged from 50 to $80 \%$, even at high temperatures. This creates favorable conditions for the carbonization of lime mortar. The curve was stable, there were no significant fluctuations in humidity. At the same time, when observing the masonry crown, which is exposed directly to external conditions, the curve of the relative humidity course was unstable and ranged between 30 and $80 \%$. At lower temperatures, a relative humidity profile was observed at approximately the same level. From the measurement results we can conclude that at temperatures lower than $5^{\circ} \mathrm{C}$ the efficiency of the cover is no longer high. This was also confirmed by measurements from the Monastery.

The results of measurements in the summer period show us that the course of temperatures and the onset of rapid heating of the masonry crown in comparison with the vegetation cover is significant. Hard cap tended to accumulate heat quickly, the measured values show that the onset of heating began to change significantly after 13.00. and the crown was exposed to extreme temperatures until the evening. The course in the soft wall cap was different, the temperature gradually accumulated in the cover during the day, its onset was not significant compared to the masonry crown. At the same time, we can observe that the soft wall cap gradually reaches the average maximum values of the hard wall cap in the evening at sunset. We do not see an extreme difference in reaching the maximum temperature on the wall cap surface. The only difference is in the time and manner of temperature accumulation in the crown. The average temperature in the vegetation cover reaches the total value during the day approximately $2^{\circ} \mathrm{C}$ lower than in the brick crown. From the given results of measurements, we can state that in the vegetation crown in comparison with the brick crown there is a certain delay (delay) of the action of temperatures.

The results of measurements in the summer period shows us that the course of temperatures and rapid onset of heating a hard wall cap, compared with soft wall cap, is significant. Hard cap tended to rapidly accumulate heat; the measurements show that the onset of the heating began to change after 13.00. And a wall cap was exhibited until the evening hours to extreme temperatures. The course of the soft wall cap was different, the temperature is gradually throughout the day as soft wall cap accumulated, its onset was not significant compared with hard cap. In doing so, we can see that the soft cap gradually in the evening when the sun gets into the average maximum values of hard cap. In reaching the maximum temperature on the surface of the wall cap, we do not see the extreme differences. The only difference is in time and accumulation in the wall cap. The average temperature in the soft wall caps reaches the total value during the day by about $2{ }^{\circ} \mathrm{C}$ lower than in a hard cap. From those measurement results, we can conclude that the soft wall capping compared with hard wall capping occurs the delay of temperatures.

\section{Čachtice castle}

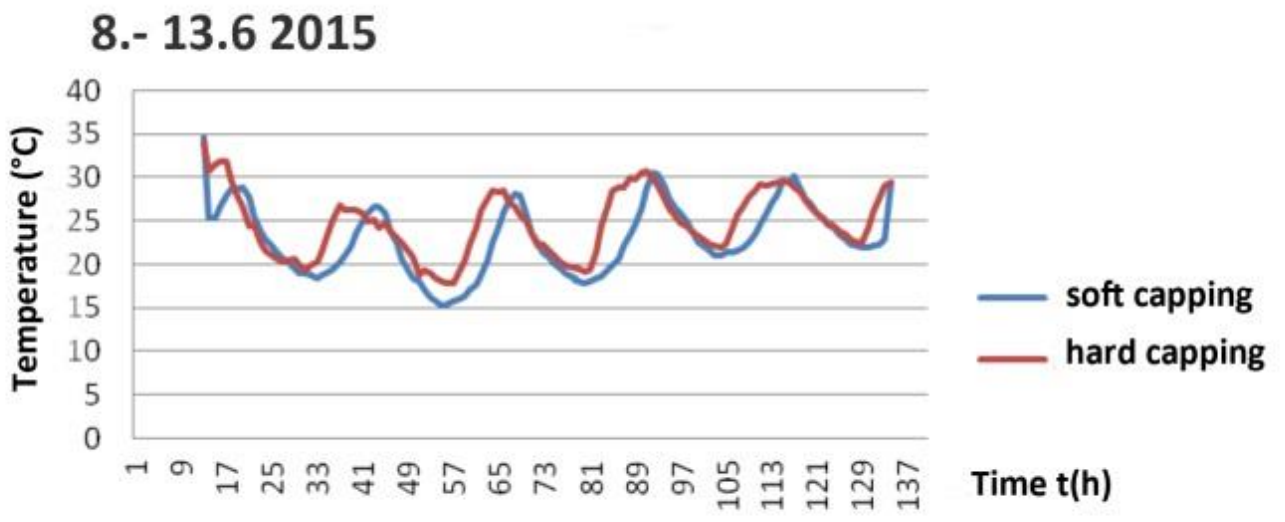

Fig. 7. Summer temperature measurement (Schlesinger, 2015) 
Relative humidity measurements once again confirmed a more constant course of temperatures in the soft wall caps, which plays an important role in the summer months. Especially during the realization of the cover and preservation of the wall cap in this period, the lime mortar is dried, the mortar is not able to carbonize, increase its strength and therefore the effectiveness of preservation on the crown is less effective and can eventually degrade the crown. The average relative humidity under the vegetation cover during the measurements was $72.24 \%$. However, it is important that no higher deviations of the values were found in the measurements. For masonry crowns, the average measured value of relative humidity was $64.37 \%$, while the relative humidity was not constant and there were larger deviations in the measured values.

\section{Čachtice castle}

\section{8.- 13.62015}

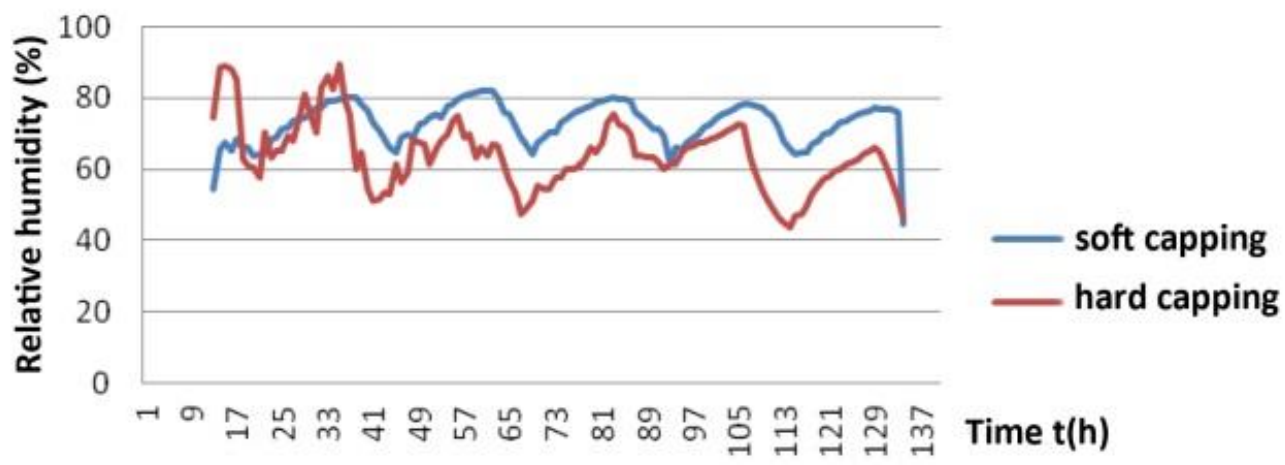

Fig. 8. Summer measurement of relative humidity (Schlesinger, 2015)

\section{CONCLUSION}

The success of the use of soft wall capping should be given by a professional study of the given material composition, construction and location of the torso.

Based on the measurements, we conclude from these locations that soft wall cap can effectively accumulate more energy and temperature as a hard wall cap. The experiments at two locations confirmed that soft wall cap provides adequate protection against extreme temperature fluctuations in wall caps on castle ruins.

\section{REFERENCE LIST}

Ashurst, J. (2007). Conservation of ruins. Oxford: Buttenworth-Heinemann, pp.180.

Plaček, M., Bóna, M. (2007). Encyklopédia slovenských hradov, Bratislava: SLOVART, spol. s.r.o., pp. 390.

Kolektív Autorov. (2006). Ochrana zrúcanín v kultúrnej krajine. Lietava: Združenie na záchranu Lietavského hradu, pp.144 .

Kolektív Autorov. (2006). Ochrana zrúcanín v kultúrnej krajine. Lietava: Združenie na záchranu Lietavského hradu, pp.146.

Kreuziger, K. (2010). DenkmalPflege, Die ingenieur-bilogishe Mauerkronensicherung und ihre Anwendung bei Bauwerken aus naturstein (II), pp.13.

Kohút, V. (2010). Metodický podklad pre statické zabezpečenie hradných ruín. Bratislava: Ateliér pre projektovanie a diagnostiku stavieb.

Kohút, V. - Staník, I. - Závacký, J. - Makýš, O. (2010). Pasportizácia zrúcanín. Bratislava: Renesans, s.r.o., Bratislava, pp.74 .

Shawkat, S. (2017). Element Design to Shape a Structure II, Tribun EU, pp. 152. 